\title{
TORAYAAN MENJALIN DAN MERAYAKAN KERUKUNAN (PRAKTIK KERUKUNAN UMAT BERAGAMA DI TONDOK LEPONGAN BULAN TANA TORAJA)
}

\section{TORAYAAN ESTABLISHING AND CELEBRATES HARMONY (RELIGIOUS HARMONY PRACTICES IN TANA TORAJA THE LEPONGAN BULAN VILLAGE)}

\author{
Paisal \\ Balai Penelitian dan Pengembangan Agama \\ J1. AP. Pettarani No. 72 Makassar \\ Email: fawwaz.mowafiq@gmail.com
}

Naskah diterima tanggal 19 Juli 2019, Naskah direvisi tanggal 16 Agustus 2019, Naskah disetujui tanggal 5 Oktober 2019

\begin{abstract}
Abstrak
Praktik kerukunan antar umat beragama pada masyarakat Tana Toraja terbentuk dan berjalan secara alamiah. Realitas masyarakat di Kabupaten Tana Toraja setidaknya menganut umat agama/kepercayaan yaitu pertama, Aluk Todolo (Agama/kepercayaan Lokal), kedua, agama Kristen yang merupakan agama mayoritas, ketiga yaitu agama Katolik dan keempat Agama Islam. Warga Toraja dalam kehidupan sosialnya tetap berdampingan sejak lama tanpa terjadi konflik sampai saat ini. Studi ini memfokuskan pada bagaimana warga Tana Toraja yang terdiri dari beberapa agama itu bisa hidup bersama secara damai? Bagaimana cara masyarakat dari komunitas bersangkutan menjalankan relasi yang aktif dan harmonis dalam berbagai aspek kehidupan? Penelitian ini menggunakan pendekatan kualitatif yang didukung dengan wawancara mendalam, pengamatan terlibat dan studi literatur. Penelitian lapangan dilaksanakan di wilayah Gandangbatu Sillanan pemilihan lokasi dengan komposisi pemeluk agama berimbang tersebut bertujuan untuk melihat relasi antar umat yang lebih luas dalam kehidupan keseharian warga. Temuan studi ini menunjukkan bahwa praktik kerukunan umat beragama tersebut tercipta berkat kearifan lokal dan kecintaan warga terhadap kehidupan yang damai dalam kebersamaan. Kearifan lokal tersebut diadopsi dari falsafah tongkonan dan menurun menjadi pepasan (pesan) lisan diantaranya dalam bentuk ujaran siangga (saling menghargai) dan siangkaran (saling tolong menolong).
\end{abstract}

kata kunci : tana toraja, kerukunan, kearifan lokal, tongkonan

\begin{abstract}
The practice of religious harmony in the Tana Toraja community is formed and runs naturally. The reality of the people in Tana Toraja Regency at least adheres to the religious / belief community, namely first, Aluk Todolo (local religion), second, Christianity which is the majority religion, third, namely Catholicism and fourthly Islam. The people of Toraja in their social lives have remained side by side for a long time without conflicts to this day. This study focuses on how Tana Toraja residents, consisting of several religions, can live together peacefully? How do people from the community concerned carry out active and harmonious relations in various aspects of life? This study uses a qualitative approach that is supported by in-depth interviews, engaged observations and literature studies. The field research was carried out in the Gandangbatu Sillanan area, where the selection of locations with balanced religious adherents was aimed at looking at wider inter-community relations in people's daily lives. The findings of this study show that the practice of religious harmony is created thanks to local wisdom and love of citizens towards a peaceful life in togetherness. The local wisdom was adopted from the philosophy of tongkonan and decreased to an oral pepasan (message) including in the form of utterances (mutual respect) and siangkaran (mutual help).
\end{abstract}

keywords: tana toraja, harmony, local wisdom, tongkonan

\section{PENDAHULUAN}

Torayaan Menjalin dan Merayakan Kerukunan (Praktik KUB di Tondok Lepongan Bulan Tana Toraja - Paisal | 321 
$\mathrm{P}$ uralitas agama merupakan fenomena realitas sosial yang tidak dapat dielakkan dalam kehidupan ini. Adanya pluralitas atau kemajemukan sebenarnya merupakan suatu rahmat yang patut untuk disyukuri, akan tetapi sekaligus juga merupakan suatu tantangan bagi umat beragama itu sendiri, karena dalam kemajemukan biasanya sarat dengan kepentingan yang sering popular disebut conflict interest. Sering kali keragaman dan kemajemukan rentan menjadi sumber konflik dan perselisihan.

Konflik antar umat beragama dalam masyarakat plural yang mensinyalir atas nama agama tidak dapat dielakkan, karena persoalan agama dalam diri manusia merupakan persoalan yang dapat membawa pada suatu keyakinan dalam prinsip agama tertentu. Dengan adanya prinsip salah satu agama yang diyakini tersebut, maka akan melahirkan suatu pandangan, kebutuhan, tanggapan dan struktur motivasi yang beraneka. Sebagai wujud konkretnya dapat ditunjukkan secara jelas dalam beberapa prinsip keagamaan yang ada dalam agama tersebut. Dengan demikian dapat terlihat jelas perbedaannya antara kebutuhan dan pandangan kelompok dalam kehidupan bermasyarakat. Oleh karena itu, untuk mewujudkan kerukunan hidup antara umat beragama yang sejati, harus tercipta satu konsep hidup bernegara yang mengikat semua anggota kelompok sosial yang berbeda agama untuk menghindari terjadinya konflik antar umat beragama.

Dengan gambaran realitas di atas, dan berangkat dari adanya salah satu keunikan dalam realitas yang cukup menarik, bahwa ada satu daerah di provinsi Sulawesi Selatan yaitu Kabupaten Tana Toraja yang masyarakatnya rukun dan harmonis. Realitasnya masyarakat di Kabupaten Tana Toraja setidaknya menganut empat kepercayaan yaitu pertama, Aluk Todolo atau aturan hidup, kedua, agama Kristen yang merupakan agama mayoritas, ketiga yaitu agama Katholik an yang keempat agama Islam. Dalam kehidupan sehari-hari berbagai komunitas agama tersebut sosialnya tetap berdampingan sejak lama tanpa terjadi konflik sampai saat ini.
Salah satu perekat kerukunan adalah terdapatnya kearifan lokal yang ada pada masyarakat tersebut. Di banding dengan ajaran agama masing-masing kelompok yang bersifat universal, kearifan lokal relatif lebih bisa diterima sebagai praktik bersama di masyarakat. Masyarakat Tanah Toraja misalnya, mereka bisa membangun kehidupan yang guyub hingga hari ini karena ditunjang oleh kearifan lokal yang disebut dengan tongkonan. Tongkonan ini menjadi sistem sosial-budaya yang mempersatukan rumpun keluarga yang berbeda agama.

Realitas lain yang tidak dapat disangkal yaitu adanya tempat-tempat ibadah seperti Masjid dan Gereja yang letaknya saling berdekatan. Bahkan dalam satu rumah ada yang berbeda agama. Namun, posisi/keadaan tersebut tidak juga menjadi suatu hal yang mempengaruhi ataupun menjadi suatu pemicu terjadinya konflik antar umat beragama dalam kehidupan masyarakat di Kabupaten Tana Toraja. Kondisi demikian dapat terlihat karena masih adanya kehangatan, keakraban bertetangga, hubungan keluarga dan berhubungan sosial antar umat beragama yang satu dengan yang lain dalam masyarakat terlihat begitu kentalnya.

\section{Tinjauan Pustaka}

Dalam penelitian ini yang digunakan istilah Best Practice Kerukunan umat beragama yang bermakna satu metode, praktik dan aktivitas hubungan masyarakat beda agama yang berhasil membangun kerukunan yang sangat baik. Dalam penelitian ini kategori Best Practice, antara lain; Pertama, Terdapat satu komunitas lebih dari satu agama yang hidup rukun dan damai. Kedua, terjadi praktik toleransi yang aktif, di mana antara warga yang beda agama tidak hanya sekedar hidup damai, tapi juga berinteraksi dengan pemeluk agama lain dan bekerja sama dalam berbagai bidang. Ketiga, memiliki mekanisme penyelesaian konflik yang bersumber dari kearifan lokal di komunitas bersangkutan (bisa berupa norma, ajaran, metode dan praktik yang khas lokal dari komunitas bersangkutan). Keempat, Praktik rukun itu berlangsung cukup lama dan berdaya guna bagi masyarakat setempat. Kelima, praktik kerukunan pada komunitas tersebut 
bisa menjadi contoh atau inspirasi dalam mengembangkan kerukunan di tempat lain.

Untuk kepentingan Best Practices kerukunan beragama ini maka model-model kerukunan yang melampaui toleransi millet (Walzer: 1997), patut untuk ditelusuri. Dengan kata lain, salah satu syarat komunitas tertentu bisa dianggap sebagai Best Practices Kerukunan Beragama adalah sejauh mana toleransi dalam komunitas bersangkutan diterapkan atas kebebasan individu dalam menjalankan agamanya masing-masing. Bagaimana komunitas itu memberlakukan individu yang memilih agama berbeda dengan yang dianut sebelumnya, bagaimana memosisikan kelompok sempalan dan bagaimana memberlakukan kelompok yang dianggap oleh mayoritas masyarakat sebagai kelompok sesat, bisa menjadi ukuran, toleransi yang berjalan, kategori aktif atau tidak.

Selain yang diudarkan di atas, toleransi aktif juga telah digambarkan oleh Walzer (1997), khususnya pada tiga matra terakhir dari apa yang disebutnya rezim toleransi, yakni; Pertama, menerima dan mengakui bahwa orang lain memiliki hak. Kedua, Tidak hanya sebatas memperlihatkan pengakuan, tetapi juga keterbukaan pada yang lain, atau setidaknya keingintahuan untuk lebih dapat memahami sang lian. Ketiga; Mendukung, merawat dan merayakan perbedaan. Bisa karena alasan bahwa keragaman itu sudah sunnatullah, juga karena alasan bahwa keragaman adalah lahan untuk menyemai perkembangan manusia menjadi lebih baik.

Diana L. Eck (2006) mengajukan konsep lain yang disebutnya pluralisme. Pluralism is not just tolerance, [but...] the energetic engagement with diversity (Pluralisme bukan sebatas toleransi [tetapi..] sikap penuh semangat dan perilaku aktif mengalami perjumpaan di tengah keragaman). Diana L. Eck lantas mengajukan tiga hal terkait dengan pluralisme ini; Pertama, pluralisme adalah keterlibatan aktif di tengah keragaman dan perbedaan. Hal ini berarti sikap yang membiarkan agama lain ada, tetapi menganggapnya tidak memiliki arti sama sekali, tidak boleh ada. Kedua, pluralisme adalah upaya memahami secara konstruktif agama atau kelompok lain yang berbeda. Dalam situasi ini sikap penuh prasangka dan curiga harus dihilangkan. Ketiga pluralisme adalah upaya menemukan komitmen bersama di tengah beragam komitmen (L. Eck, 2006: $1)$.

Penelitian menggunakan metode kualitatif-etnografis yang dilakukan dengan cara mendeskripsikan data secara sistematis, faktual dan akurat. Sementara disebut etnografis, karena berupaya menggambarkan secara detail praktik kerukunan pada satu masyarakat atau komunitas tertentu, termasuk mendeskripsikan kebudayaan dan kearifan lokal yang mendukung kerukunan tersebut (Spradley, 1997). Adapun informan penelitian ini secara umum adalah masyarakat yang berada dalam lingkungan komunitas yang mempraktikkan kerukunan beragama dengan baik di Lembang Kaduaja dan Lembang Garassik. Lebih spesifik lagi adalah tokoh agama, tokoh masyarakat dan pemerintah di Tana Toraja.

\section{Gandangbatu Sillanan dalam Harmoni Alam yang Memukau}

Kecamatan Gandangbatu Sillanan adalah sebuah kecamatan di bagian selatan Kabupaten Tana Toraja. Saya menyebutnya sorga, alamnya indah dan diberkati. Terletak pada ketinggian 800- $1.300 \mathrm{mdpl}$, bersuhu dingin dengan curah hujan yang cukup tinggi. Potensi yang dimiliki daerah ini pada bidang pertanian, perkebunan dan peternakan. Kecamatan ini penghasil kopi dan holtikultura, mereka juga beternak ayam, kambing, sapi, kerbau dan babi. Masyarakatnya ramah dan bersahabat. Kecamatan Gandangbatu Sillanan yang keadaan wilayahnya terdiri dari pegunungan terletak di selatan Makale dengan jarak tempuh $30 \mathrm{Km}$ dari Ibukota Kecamatan ke Ibukota Kabupaten.

Dalam buku Profil Kecamatan disebutkan Gandangbatu Sillanan terdiri atas kata Gandang yang berarti Gendang dan Batu (batu pada umumnya). Gandangbatu Sillanan berasal dari 2 kampung yaitu Gandangbatu dan Sillanan, yang dalam bahasa Toraja disebut Tondo Dipadiong Lisunna Pala', Dipalan Se'ponna Kalepa' Sang Sipairisan Angin 
Dibuntu, Tangsi Painbong, Tangdikallean Malamu' Si Sapu Lentek Mangugantanan Sirenden Palak yang berarti saling peduli di kedua belah pihak, misalnya di Gandangbatu bersuka ria, Sillanan turut bersuka ria dan sebaliknya jika Sillanan berduka cita Gandangbatu turut merasakan. Gadangbatu Sillanan disebut Tondok Da'dua Bua'na dan Tondok Ma'Palampang Batu yaitu wilayah pemerintahan adat disatukan dan kedua kampung merupakan dua hamparan gunung batu yang memiliki motif dan bentuk yang serupa.

Pada sisi lain disebut Gandangbatu Sillanan karena budaya di Sillanan berasal dari Gandangbatu sehingga dengan demikian digabung menjadi satu kecamatan dan juga sebagai tempat pemantauan karena ada kesepakatan untuk satu rasa dan hidup berdampingan, sehingga menjadi sebuah Kecamatan yang saat ini bernama Gandangbatu Sillanan, yang ibukota kecamatannya terletak di Kelurahan Benteng Ambeso. Kecamatan Gandangbatu Sillanan di bentuk berdasarkan Peraturan Daerah Nomor 18 Tahun 2000.

Gandangbatu Sillanan dibatasi: pada sebelah utara: Kecamatan Makale Selatan, sebelah Selatan: Kecamatan Alla, Kabupaten Enrekang, sebelah Timur: Kecamatan Mengkendek; dan pada sebelah barat: Kecamatan Rano dan Kecamatan Makale Selatan. Secara administratif Kecamatan Gandangbatu Sillanan terdiri dari 3 kelurahan dan 9 Lembang sebagai berikut: 1. Kelurahan Benteng Ambeso; 2. Kelurahan Salubarani; Kelurahan Mebali; 4. Lembang Garassik; 5. Lembang Perindingan; 6. Lembang Pemanukan 7. Lembang Betteng Deata; 8. Lembang Buntu Tabang 9. Lembang Sillanan; Lembang Gandangbatu; 11. Lembang Buntu Limbong; 12. Lembang Kaduaja. Penduduknya mayoritas merupakan suku Toraja dan Duri sebagian kecil orang Bugis. Dalam segi agama, Islam 5.821 jiwa, Katolik 2.966, Kristen 10.311, dan Hindu (Aluk Todolo) 696 jiwa. Meski warga menganut agama yg beragam namun relasi antar umat beragama terjaga sangat baik dan aktif.
Dalam data yang penulis temukan dari BPS Tana Toraja terlihat dari 12 lembang di Gandangbatu Sillanan terdapat dua lembang yang menarik untuk diketahui lebih dalam praktik kerukunan umat beragamanya. Dua lembang tersebut adalah Lembang Kaduaja dan Lembang Garassik. Lembang Kaduaja dengan jumlah penduduk 1.214 jiwa terdiri dari 53\% beragama Kristen Protestan, 32\% beragama Islam, dan $11 \%$ Katholik, sisanya 4\% merupakan penduduk yang menganut agama Hindu Alukta. Umat Muslim di Kaduaja memiliki 2 masjid dan 2 Mushollah, Gereja Protestan 3 buah. Lembang Garassik yang terletak pada bagian timur laut Kaduaja komposisi penduduknya terdiri dari 53\% penganut Kristen Protestan, $31 \%$ beragama Islam, $12 \%$ panganut Katholik serta hanya $4 \%$ yang menganut Hindu Alukta, di Garassik terdapat 3 masjid dan 3 Gereja Protestan. Dengan demikian komposisi umat beragama pada dua lembang yang bersisian dengan Kabupaten Enrekang tersebut cukup beragam.

Lembang Kaduaja merupakan sebuah desa yang selalu menjadi percontohan dalam bidang peternakan dan perkebunan, hal ini karena etos kerja yang dimiliki penduduk desa ini yang cukup tinggi sehingga masyarakatnya hidup makmur dan berkecukupan. Kemakmuran yang dicapai berasal dari keterampilan mengolah tanah dan memelihara ternak. Sistem pengairan swadaya yang lebih banyak diusahakan sendiri para penduduk juga cukup baik yang berasal dari buntu (bukit) berbatu yang terdapat di sudut-sudut desa. Bentang alam pegunungan yang memukau dengan curah hujan yang cukup membuat kedua lembang subur nan hijau.

\section{Persentuhan Gandangbatu Sillanan dengan Kristen dan Islam}

Warga Gandangbatu Sillanan terhitung cukup lambat bersentuhan dengan Injil mengingat lokasinya yang berada di pegunungan dekat Enrekang, sulit dijangkau para missionaris. Letak geografis di selatan jauh dari Poso atau Rongkong yang disebut merupakan pintu masuknya Injil di Toraja. Juga tofografi yang berada di ketinggian sekitar $1.000 \mathrm{Mdpl}$ membuatnya terlambat menerima penginjil. 
Penyebaran Kristen dalam catatan "Sumber Zending tentang Sejarah Gereja Toraja" (End: 1991) dimulai pada Baptisan pertama di Kota Makale pada tgl 13 Maret 1913. Pada Baptisan pertama tersebut disebut 20 pemuda dibaptis yang kesemuanya adalah dari kalangan bangsawan yang sudah bersentuhan dengan pendidikan modern ala Belanda dan menerima pengajaran agama Kristen. Dalam catatan tersebut juga terdapat nama Lukas Tuppa yg berasal dari Gandangbatu. Bigalke (2016: Hal. 179) pada bagian catatan kaki mengutip dokumen Gerefoormeerde Zendingbond (sering disingkat GZB) setelah menyaringnya dengan kritis menyebutkan pada tahun 1928 jumlah pemeluk Kristen yang telah dibaptis mencapai 2.260 jiwa, tahun 1930 menunjuk angka 3.005 jiwa, 1933 sebanyak 5.660 jiwa dan pada tahun 1938 telah mencapai 11.336 jiwa. Angkaangka baptis ini menunjukkan kecenderungan dalam konversi keagamaan dari agama lokal menuju Kristen.

Di Gandangbatu pekabaran Injil diawali dengan masuknya tenaga pengajar pada tahun 1930an. Mereka cukup berjasa memperkenalkan Kristen kepada penduduk yang kesulitan berkomunikasi selain menggunakan bahasa Toraya atau yang sekelompoknya seperti bahasa Duri. Salah satu saksi hidup persentuhan warga Gandangbatu Sillanan dengan agama Kristen adalah Ne' Ari. $\mathrm{Ne}^{\prime}$ Ari berusia 20-an tahun ketika dibaptis pada tahun 1941 di Lemo, dekat Makale. Sebelumnya dia menganut keyakinan leluhur Toraja, Aluk Todolo (Alukta). Ne' Ari tercatat sebagai bagian dari kelompok pertama di daerah ini yang memeluk agama Kristen.

$\mathrm{Ne}^{\prime}$ Ari menceritakan cukup sulit memahami iman Kristen ketika pertama kalinya dan lepas dari keyakinan Alukta. Entah siapa yg memulai Tuhan Allah dalam keyakinan Kristen kemudian dalam bahasa Toraja disebut saja Puang Matua. Pribumisasi ala Kristen ini cukup berhasil mengingat Puang Matua dalam kepercayaan Alukta merupakan Deata tertinggi. Bigalke (2016: 171) berkomentar "menyamakan ketuhanan Kristen dengan suatu dewa lokal utama merupakan sebuah langkah berani untuk menyesuaikan Kristen dengan lingkungan spiritual Toraja".

$\mathrm{Ne}^{\prime}$ Ari melewati berbagai zaman, Belanda, Jepang, Belanda lagi, Gerombolan DI/TII, PKI hingga baru merasa merdeka pada tahun 1970-an pasca stabilisasi militeristik ala Orde Baru. Dari semua era itu menurutnya yang paling mengerikan adalah zaman Gerombolan DI/TII. Pada era tersebut warga tidak bisa hidup tenang, kehilangan harta benda dan harus mengungsi ke Makale atau masuk hutan di Duri, Enrekang. Selain korban tewas banyak pula yang harus kehilangan agama dan keyakinannya karena pemaksaan.

Senada dengan Ne' Ari, Ambe Anning (Wawancara Maret 2019) menceritakan pada masa DI/TII terpaksa berganti agama Islam karena takut disembelih, selama sepuluh tahun dia beragama Islam sejak tahun 1956 dan kembali menganut Kristen pasca meninggalnya pimpinan tertinggi DI/TII pada tahun 1965. Ambe Anning kemudian kembali dibaptis dengan nama Yulianus. Ambe Anning menceritakan pada awalnya gerombolan masuk ke Gandangbatu secara damai dan memperoleh simpati warga karena mempersilahkan menganut dua agama samawi Islam atau Kristen asal bukan penganut aluk Todolo. Namun, dalam tahun yang sama menurut ST (Wawancara Maret 2019) terjadi perubahan kebijakan dan Gerombolan DI/TII memaksa dan mengultimatum warga untuk memeluk agama Islam saja, warga yang awalnya simpati bahkan banyak yang beragama Kristen bersedia bergabung menjadi gerombolan kemudian diliputi ketakutan.

Ambe Anning bercerita pada saat itu warga yang memelihara babi diberi waktu seminggu untuk menyembelih dan menghabiskan sisa ternak babinya. Malang tetap tak dapat ditolak, meski warga telah mengikuti kemauan gerombolan namun tetap tak dapat menjamin keamanan diri dan keluarganya. Mereka yang tinggal di kampung dipaksa membayar pajak, sementara pada pihak lain tentara juga tak bisa melindungi dan malah seringkali bertindak brutal (lihat juga Diks Pasande dalam Van Bemmelen: 2011). Untuk mencari selamat warga mengungsi ke hutan di Duri Enrekang, atau sekalian ke kota Makale. Ne' Ari berharap kondisi itu tak 
pernah kembali, perang hanya membawa nestapa, warga Gandangbatu kini hidup damai dalam kerukunan, Islam maupun Kristen berinteraksi tanpa sekat, saling bergotong royong dalam setiap aktifitas kesehariannya, mereka mengamalkan falsafah leluhur Toraja; Siangga, Sikamali na Siangkarang (saling menghargai, saling merindukan dan saling tolong menolong).

Persebaran agama Islam di wilayah ini terjadi jauh sebelum terjadinya pemberontakan DI/TII. Islam masuk melalui jalan damai. Setelah percobaan penaklukan oleh Arung Palakka yang dianggap gagal. Ekspedisi Arung Palakka banyak terhambat di daerah Gandasil yang terletak dibalik perbukitan (buntu) Benteng Alla, Enrekang. Wilayah Alla ini tercatat dalam sejarah ketika Arung Palakka mencoba menaklukkan Tana Toraja pada tahun 1683. Benteng Buntu (Bukit) Alla yang menaungi Gandang Batu Sillanan menjadi salah satu tempat pertahanan pasukan Toraja yang sulit ditaklukkan, pasukan gabungan Arung Palakka yang dalam catatan sejarah disebut mencapai 50.000 bahkan banyak yang menjadi korban cerdiknya pasukan Toraja menguasai medan memanfaatkan kondisi geografis perbukitan untuk bertahan dan menyerang. Disebutkan selain membawa misi penaklukan memperluas wilayah kekuasaan, pasukan Arung Palakka juga disebut membawa misi Islamisasi daerah taklukan.

Sekalipun pada akhirnya terdapat satu diantara 3 Indo' Tallu Lembanna yang berunding dan dianggap takluk, tapi Toraja tak pernah benar-benar dikuasai dan ditaklukkan oleh Bone. Dalam catatan Leonard Andaya (2004: 324), Bone memberikan kebebasan penuh atas teritori dan sistem sosial daerah yang dianggap taklukannya tersebut. Andaya mencatat Toraja tak pernah takluk dan itu sejalan dengan tradisi oral yang selalu terdengar dari setiap warga Toraja yang tak mengakui penaklukan Bone.

Kajian Nurdin Baturante dalam buku

berjudul "Toraja, Tongkonan dan Kerukunan" (2019) menyebutkan 3 (tiga) versi masuknya Islam di Tana Toraja; 1) Versi Bone, versi ini cukup meragukan karena tidak terdapat data pendukung yang memadai. menurutnya memang pernah orang Bone datang pada tahun 1675-1680 tapi tujuan mereka bukan untuk misi agama melainkan untuk perang penaklukan, perdagangan dan perjudian sehingga tidak berdampak dalam penyebaran Islam. 2) Versi Teteaji, Sidrap, masuknya Islam ditandai dengan kedatangan Guru Siduppa yang berasal dari Teteaji pada akhir abad ke-19, Guru Siduppa disebut meninggalkan Teteaji karena pada saat itu telah dikuasai oleh Belanda. Jejak Guru Siduppa bersama Bora Ele (Guru Tarekat) dan Uwa' Ammada (Guru Tajwid) saat ini masih dapat ditemui pada murid dan keturunannya yang tersebar di Tana Toraja serta rintisannya yang menjadi cikal bakal Masjid Raya Makale. Versi Teteaji ini menjadi kuat karena pembinaan dan pengajaran oleh para guru tersebut menorehkan jejak peradaban Islami melalui transformasi keilmuan; 3) Versi dari Luwu Palopo menyebutkan Guru Siduppa kemudian menikah dengan Rangga seorang Tokoh Masyarakat Madandan yang telah memeluk Islam dalam perkawinan sebelumnya dengan Opu Demmakkalu' (Ambe Rukiyah) asal Luwu. Rangga disebut merupakan orang Toraja pertama yang memeluk Islam antara tahun 1876-1880 M.

Islam masuk menggunakan jalur damai melalui persentuhannya dengan daerah Massenrempulu (Enrekang) yang telah lama mengenal dan sebagian besar telah memeluk Islam. Masuknya Islam ke Sulawesi Selatan dan menjadi agama resmi kerajaan Gowa Tallo yang kemudian melancarkan perang penaklukan dan lazim disebut dengan 'Musu' Assellengang" membuat beberapa kerajaan Bugis di bagian tengah utara Sulawesi kemudian mengenal Islam. Daerah persekutuan Tellumpoccoe dan Ajatappareng yang berdekatan dengan wilayah Massenrempulu juga telah bersentuhan dengan Islam pada tahun 1607, pada tahun 1608 Maiwa telah berpihak pada Gowa (Sewang, 2005: 117). Pengaruh Islam di Massenrempulu dipertegas dengan kehadiran seorang putera Topoang yang belajar di Gowa dan kemudian diberi gelar Janggo Ridi (Janggut Kuning), Janggo Ridi disebutkan menyebarkan Islam di wilayah Kerajaan Maiwa. (Hermin Botong, 2007: 42). Setelahnya raja Maiwa berganti agama, Islam kemudian menyebar ke wilayah 
lain dalam persekutuan Massenrempulu. Catatan Van Braam Morris (Mappasanda, 1991: 41-42) yang ditulis sekitar tahun 1888, menyebut Kerajaan Alla (Duri, termasuk persekutuan Tallu Batu Papan) yang berbatasan dengan Kaduaja dan Salubarani telah memeluk Islam sejak 6 atau 7 generasi sebelumnya dan telah memiliki perangkat syara' yang terdiri dari kadi, imam khatib, bilal dan doja.

Kedekatan secara geografis dengan wilayah yang telah hampir seluruhnya memeluk Islam membuat kontak dengan warga Toraja bagian selatan ini menjadi mudah. Kedatangan beberapa saudagar Bugis beragama Islam yang berdagang di pasar Mebali juga membuka ruang perkenalan dengan Islam. Ne Sama yang kini merupakan seorang Imam Kampung di Garassik menyebutkan leluhurnya berasal dari Teteaji, sebuah daerah di Tellulimpoe Sidrap (Wawancara Maret 2019). Ne Sama yang lahir tahun 1940-an menceritakan kedatangan kakeknya sebagai pedagang pasar, menurutnya saat itu beberapa orang pedagang Bugis kemudian menikah dengan warga setempat yang menganut Aluk Todolo. Selain pengaruh Bugis, faktor lain yang mempengaruhi penyebaran Islam di Toraja adalah jalinan kekerabatan. Warga Toraja banyak yang memiliki pertalian saudara dengan tetangganya di Duri, Alla maupun daerah Luwu yang telah beragama Islam (Safruddin, wawancara Maret 2019).

Bigalke (2015: 159) mengutip dari dokumen Belanda "Volkstelling 1930, Deel V" menyebutkan "pada tahun 1914 di dan sekitar Rantepao (dengan jumlah yang mungkin lebih besar di Makale) sementara pada tahun 1930 total jumlahnya di MakaleRantepao menjadi 2.100 jiwa.”. Pedagang Bugis pada masa tersebut dapat dikatakan mendominasi hampir semua segmen perdagangan Toraja hingga pedagang Cina berhasil merebut dominasi karena dukungan modal yang besar. Pada bagian lain Bigalke (2016: Hal. 161) menulis "kemungkinan untuk menerima Islam paling besar berada di kawasan perbatasan (Palopo dan Enrekang), sebagian besar konversi agama terjadi disana. Dari 3.720 ribu jiwa penduduk Muslim (1,13 dari total penduduk) yang tinggal di Makale Rantepao tahun 1930, etnik Toraja berjumlah 1.600 atau mencapai $43 \%$ sementara sisanya adalah Bugis.

Di tempat ini dikenal istilah "Islam Garassik" yang merupakan sebuah corak keberislaman yang ramah tradisi lokal dibawa dengan jalan dakwah sejuk dan damai oleh para pedagang Bugis. Mereka diberi label "Islam Garassik" karena sebagian penganut Islam di Garassik masih melaksanakan tradisi Bugis yang disebut "Mattoana" (MA. Wawancara Maret 2019). Mattoana dilaksanakan ketika selesai panen, ada hajat telah terkabul atau memperoleh nikmat yang patut disyukuri. Kegiatannya berupa pembacaan doa syukuran dengan mengundang keluarga, tetangga, sanak kerabat untuk makan sokko (nasi dari ketan: bugis) dan biasanya disantap dengan ayam secara bersama-sama. Pada saat pembacaan doa syukuran disertai dengan pembakaran dupa oleh Imam atau Guru Sara'.

Selain tradisi syukuran mattoana, umat Islam Garassik juga melaksanakan tahlilan 3, 7 sampai 40 hari bagi orang yang meninggal. Mereka juga mengenal pembacaan kitab al-Barzanji dalam setiap hajatan berupa aqiqah, khitanan, maupun pernikahan atau /menempati rumah baru. Tradisi ini telah berlangsung turun temurun, meski kini ada yang meninggalkannya karena menganggap tidak ada perintahnya dalam Alquran (Ibid. MA). MA bertutur sebenarnya pelabelan Islam Garassik kurang tepat karena seperti pengkotak-kotakan "umat Islam di Garassik dan sekitarnya tidak akan sebanyak ini jika tidak melalui dakwah orang Bugis yang merangkul tradisi dan budaya, kalah kita dengan penginjil Toraja yang mampu beradaptasi dengan warga setempat". Warga Toraja yang menganut Aluk Todolo memang banyak mengenal tradisi syukuran dalam beberapa kegiatan dan dengan memusuhi tradisi leluhur mereka akan sangat susah memperkenalkan Islam. Jalan mengenalkan Islam dengan membawa tradisi yang juga umumnya dilaksanakan oleh umat Muslim di daerah lain dipandang tepat mengingat tradisi syukuran tersebut telah dihiasi dengan doa-doa yang Islami. Menurut Ne Sama' penganut 
Islam Garassik banyak yang menjadi korban keganasan gerombolan DI/TII pada masa lalu karena dianggap sesat, mereka menganggap ritual syukuran dengan menggunakan tradisi seperti itu tidak ada tuntunannya dalam syariat.

Bigalke (2015: Hal 158) menulis bagaimana pergulatan Islam dengan kepercayaan lokal "Islam pada pemukimpemukim Muslim paling awal dan orangorang Toraja "Muallaf" tergolong lunak dan toleran terhadap kebiasaan lokal. Memang, agama dari banyak pembawa awal ini menanamkan dogma Islam dengan kepercayaan pra Islam dalam kadar yang tinggi, yang secara spiritual memberi mereka banyak kesamaan dengan sepupu-sepupu Toraja mereka. Kedalaman ketaatan mereka kepada Islam amat tergantung kepada pekerjaan, pelatihan keagamaan formal dan tempat asal. Praktik Islam dari seorang pedagang kopi kecil dari Duri, yang hanya dipisahkan sebuah sungai dari dataran tinggi sa'dan, mungkin kurang sempurna dibandingkan dengan yang dipunyai oleh seorang pedagang kaya dari Pare-pare".

Menandai keberadaan umat Islam di Garassik didirikan sebuah masjid pada awal abad ke-20. Masjid itu bernama Masjid Taqwa Garassik, dibangun secara swadaya berkat inisiasi para pendatang Muslim dari Bugis, saat itu pemeluk agama Islam kebanyakan masih orang Bugis. Pada tahun 1970-an bagian beranda masjid ini sempat digunakan sebagai Madrasah Diniyah Ibtidaiyah. Madrasah tersebut kemudian dipindahkan ke Tondok Garotin yang berjarak sekitar $3 \mathrm{Km}$, tempat yang kini menjadi lokasi masjid $\mathrm{Al} \mathrm{Fattah} \mathrm{yang}$ berdampingan dengan Gereja Toraja Jemaat Garotin.

Sebelum persebaran agama Samawi (Kristen, Katholik dan Islam) orang Toraja memiliki agama lokal sendiri yakni Aluk Todolo. Banyak pihak yang menganggap Aluk Todolo bukanlah sebuah agama dan orang Toraja tak beragama, Aluk Todolo dianggap hanya sebagai keyakinan adanya kekuatan di luar dirinya, sulit bagi banyak orang untuk menyamakan Aluk Todolo sebagai sebuah agama atau system kepercayaan yang memiliki konsep ketuhanannya sendiri, Aluk Todolo hanyalah dianggap sebagai sebuah kepercayaan animism.

Aluk Todolo menurut Theodorus Kobong (2008: 121) adalah "agama para leluhur, atau cara hidup atau aturan hidup para leluhur. Kepercayaan ini sebelumnya pada masa orde baru sebagaimana agama dan kepercayaan lokal lain tidak mendapat pengakuan sebagai aliran kepercayaan yang diakui dalam Negara Republik Indonesia. Masa orde baru hanya mengakui lima agama resmi yang kemudian dalam orde reformasi pada masa pemerintahan Gusdur bertambah menjadi 6 agama resmi, yakni Islam, Kristen, Katolik, Hindu, Budha, dan yang terakhir Khonghuchu.

Dalam perjalanannya Aluk Todolo kemudian dimasukkan sebagai aliran Hindu Dharma Aluk Todolo atau sejenis dengan agama Hindu Bali, kemudian dikenal dengan Hindu Alukta, Alukta ini bermakna Aluk Kita atau Agama Kita. Hal ini tertuang dalam SK Direktorat Jenderal Bimas Hindu-Budha Nomor Dd/H/200-VII/69 tanggal 15 November 1969 yang menyatakan Aluk Todolo adalah bagian dari Hindu. Menempel atau menjadi bagian agama resmi merupakan satu-satunya cara agar tidak dianggap atheis atau komunis. Meski menurut salah seorang penganut Aluk Todolo (ML, Wawancara Maret 2019) yang penulis temui agak sulit menyamakan dengan konsep ketuhanan Hindu yakni dewa-dewa Brahma, Siwa dan Wisnu. Aluk Todolo mempercayai Tuhan yang disebut Puang Matua, mereka percaya Puang Matua adalah pencipta langit dan bumi dan memiliki atau menguasainya.

Kini, para penghayat kepercayaan di Indonesia atau yang disebut sebagai penganut agama lokal semisal Aluk Todolo ini boleh bernapas lega. Perjuangan mereka mendapat pengakuan negara dalam catatan administrasi kependudukan lewat uji materi UndangUndang Administrasi Kependudukan dikabulkan Mahkamah Konstitusi (MK), Selasa, 7 November 2017.

Putusan MK menyatakan bahwa penghayat kepercayaan dapat dicantumkan dalam kolom agama pada kartu keluarga (KK) dan kartu tanda penduduk elektronik (e-KTP) tanpa perlu merinci aliran kepercayaan yang 
dianut. Menurut Bab I, Pasal 1 Ayat 2 Peraturan Bersama Menteri Nomor 43 dan 41 Tahun 2009 pengertian Penghayat Kepercayaan terhadap Tuhan Yang Maha Esa adalah pernyataan dan pelaksanaan hubungan pribadi dengan Tuhan Yang Maha Esa berdasarkan keyakinan yang diwujudkan dengan perilaku ketakwaan terhadap Tuhan Yang Maha Esa serta pengamalan budi luhur yang ajarannya bersumber dari kearifan lokal bangsa Indonesia.

Agama-agama suku, seperti Aluk Todolo (Alukta) di Toraja masuk kategori penghayat kepercayaan ini. Keputusan Mahkamah Konstitusi ini tentu saja memberi angin segar kepada para penganut Aluk Todolo, yang selama ini diabaikan, dianggap tidak ada, mengalami diskriminasi sosial, serta kesulitan mendapat akses terhadap layanan sosial yang dinikmati oleh warga negara lain. Meski sudah diakui dan dapat dicantumkan dalam kolom agama di KTP namun tak banyak penganut Aluk Todolo yang melakukannya, selain karena menurut mereka KTP sudah terlanjur jadi juga karena kemalasan, apalah arti sebuah nama agama jika selama ini keyakinan juga tetap seperti itu meski disebut Hindu. Dalam data catatan sipil Kabupaten Tana Toraja hanya terdapat 26 orang dan 23 orang di Kab. Toraja Utara yang mencantumkan agama Aluk Todolo.

Data BPS tahun 2018 menunjukkan dari total jumlah penduduk sebanyak 231.519 jiwa yang terdiri atas 117.030 jiwa penduduk laki -laki dan 114.489 jiwa penduduk perempuan, terdapat 34.275 jiwa penganut agama Islam, 184. 875 jiwa penganut agama Kristen, 50.158 penganut Agama Katolik, 10.214 Hindu dan 19 orang penganut agama Budha. Dalam data yang diperoleh dari Kementerian Agama Tana Toraja juga sama tidak terdapat data penganut agama Khonghuchu dan aliran kepercayaan. Dapat dikatakan hampir seluruh penganut Hindu dalam data tersebut merupakan Hindu Alukta.

Dalam data tersebut menunjukkan mayoritas warga Toraja yakni sekitar $75 \%$ menganut Agama Kristen, sisanya adalah Katholik, Islam dan Hindu. Identitas asli Toraja yang seharusnya Aluk Todolo tak lagi dominan. Meski begitu ajaran Aluk Todolo dalam kehidupan masyarakat Toraja tak bisa hilang begitu saja. Beberapa tradisi leluhur tetap dilaksanakan dengan corak berbeda baik bagi yang beragama Islam maupun yang non Muslim.

Aluk Todolo mentransformasikan ajaran kepercayaannya melalui pesan leluhur (pepasan todiolo) yang disampaikan melalui tradisi lisan turun temurun. Pimpinan adat disebut sebagai to parenge'. Dalam bahasa Toraja, to berarti orang dan renge' berarti "mengambil suatu beban dengan tali melalui kepala." Adapun pemuka Aluk Tadolo disebut to minaa, yang dalam bahasa Toraja bisa diartikan "orang yang pandai mendoakan." To Parenge dan To minaa merupakan pemuka agama Aluk Todolo yang berperan menyampaikan pesan leluhur tersebut. Menurut Institut Theologia Gereja Toraja (1984), seperti dikutip Theodorus Kobong, "Aluk dan adat merupakan satu kesatuan, keduanya saling berkaitan dan tidak dapat dipisahkan. Harus ditekankan Aluk adalah sumber bagi adat." Aluk dan adat begitu berpengaruh dalam hubungan antar-keluarga di tongkonon atau rumah adat Toraja, Demikian pula pengaruhnya dalam hubungan kekerabatan masyarakat Toraja yang sangat erat.

\section{Praktik Kerukunan Umat Beragama di Lembang Kaduaja dan Lembang Garassik}

Dalam amatan keseharian warga kedua lembang tersebut, warga tak mempersoalkan identitas agama, mereka tetap menjalin hubungan dengan kerabat ataupun orang lain yang berbeda agama. Relasi aktif mereka tunjukkan dalam kehidupan seharihari; relasi persahabatan, saling membantu bergotong royong dalam aktifitas pertanian bahkan hingga keterlibatan aktif dlm pembangunan rumah ibadat umat lain. Disini bahkan banyak ditemukan warga yang dalam satu rumah berbeda agama, ada yang ayahnya Hindu (Alukta) anaknya Kristen, ayah ibunya Haji dan menjabat bahkan menjabat Imam sementara anak-anaknya semua Kristen, ada pula yang suaminya imam istrinya pendeta Kristen.

Potret lain indahnya hidup berdampingan dengan yang berbeda agama. Di 
lembang Garassik, Tondok Garotin, Kec. Gandangbatu Sillanan, Tana Toraja Sulsel pada sebuah tempat yg sama Masjid dan Gereja dibangun berdampingan oleh warga secara swadaya.Namanya Gereja Toraja Jemaat Garotin dan Masjid Al Fattah Garotin. Gereja dibangun hampir bersamaan dgn masjid pada tahun 1966. Awalnya kecil saja dua rumah ibadat berbeda ini namun seiring perkembangan jemaat kemudian direhab dan diperbesar daya tampungnya. Terlihat pada foto Masjid tua yg dibangun sejak 1966 disamping masjid yg kini sedang dibangun berlantai 2 .

Proses pembangunan 2 rumah ibadat ini juga saling membantu antar 2 jemaat agama berbeda ini, baik dalam hal pendanaan maupun pengerjaan pembangunan bahkan hingga personil kepanitiaan. Begitupula dlm beberapa kegiatan keagamaan baik Kristen atau Muslim kedua komunitas saling berbaur dan saling membantu. Pada halaman depan gereja terdapat puluhan kuburan muslim yang terawat dgn cukup baik.

Pernah terjadi riak-riak kecil karena kesalahfahaman namun dapat diselesaikan dengan cepat oleh masyarakat Muslim dan Kristen Garassik. Menurut keterangan FKUB dan Pemerintah, kesalahfahaman terjadi akibat kesalahan administrasi pertanahan dalam menerbitkan sertifikat, pertanahan menggunakan informasi orang luar yang bukan pemilik tanah di Tondok Garotin dalam penentuan batas tanah. Informasi yang beredar dari mulut ke mulut di masyarakat diperparah dengan isu adanya Masjid yang akan digusur yang membuat massa Muslim menjadi geram dan berkumpul.

Yang terjadi warga Muslim dan Kristen yang sempat bersitegang kemudian berkumpul dan sebagian bersama-sama menuju rumah jabatan bupati dan kantor Bupati Tana Toraja untuk mempertanyakan penetapan batas tanah yang dilakukan oleh BPN. Ketua FKUB saat itu sempat berkunjung ke Garotin untuk meninjau lokasi dan memberikan arahan pada warga untuk tetap menjalin silaturrahmi dan menjaga kerukunan antar umat beragama, beliau juga mengatakan agar jangan mudah terprovokasi mengingat lokasi terebut berbatasan dengan Enrekang yang mayoritas Muslim.

Kejadian pada sekitar tahun 2011 masa bupati Theofillus Allorerung tersebut berhasil diredam dan tidak terekspose karena dianggap tidak ada masalah antar agama namun terjadi kesalahfahaman antar warga pengelola tanah wakaf dengan pemerintah. Beberapa tokoh masyarakat dan politisi Muslim menganggap ini terjadi karena dipolitisir mengingat makin kuatnya pengaruh Islam di Garassik. Berkat kesadaran warganya sendiri yang sejak lama saling berbaur dan berinteraksi tanpa peduli sekat agama dapat mencegah terjadinya ketegangan yang lebih besar. Pada akhirnya pemuda yang menyebar isu adanya penggusuran masjid meminta maaf dan mengakui kesalahannya ( $\mathrm{Ne}$ Sama, Wawancara 2019).

Menurut M.A (Wawancara Maret 2019) permasalahan muncul berawal dari tekanan yang dialami warga muslim dalam pendirian masjid. "Beberapa kali kami menghadapi aparat mulai dari tingkat bawah hingga bupati dan BPN yang tak mampu menyelesaikan persoalan hak atas tanah ini, tanah masjid ini adalah tanah wakaf yang telah terdaftar di Kemenag dengan lebar 55 meter dan panjang 58 meter atau tertulis 3.190 Meter Persegi. Akta Ikrar wakaf tersebut ditandatangani pada tanggal 28 desember 1982. Setifikat Hak atas tanah wakaf kemudian hari terbit namun tidak dikeluarkan (disembunyikan) oleh beberapa oknum BPN. Sertifikat kemudian keluar dengan bantuan beberapa pihak, dalam sertifikat tersebut hanya tertulis 2.200 meter persegi." Hingga kini persoalan hak atas tanah ini masih menjad momok yang cukup berbahaya dan dianggap mencederai masyarakat Tondok Garotin yang selama ini hidup rukun dan harmonis.

Masjid dan gereja yang berdampingan tersebut terukir dalam dinamika sejarah yang cukup panjang. Sejarah sosial yang terekam dalam memori kolektif warga menyiratkan relasi harmonis yang terjalin sejak lama. Pada awalnya tahun 1969-1981 di lokasi Masjid maupun gereja tersebut terdapat sebuah Madrasah Ibtidaiyah yang kemudian ditutup setelah mencoba bertahan beberapa tahun dengan jumlah murid yang hanya segelintir 
dan tenaga pengajar terbatas. Pernah juga ada yang mencoba mendirikan Sekolah Kristen di lokasi tersebut namun kemudian batal karena penolakan warga muslim yang menganggap itu adalah tanah wakaf warga muslim.

Sebelumnya di lokasi tersebut dibangun sebuah masjid (mushollah) kecil berukuran 7x7 meter, berlantai semen kasar dengan dinding kayu. Pembangunan masjid tersebut melibatkan umat Muslim dan Kristen setempat, tradisi gotong royong warga memang masih sangat kuat di tondok ini. Beberapa tokoh masyarakat Muslim yang menjadi penggerak pembangunan masjid ini memang memiliki hubungan kekerabatan yang cukup erat dengan warga non Muslim, keluarga dengan beragam agama itu tidak menghalangi kebiasaan saling membantu.

Kini di lokasi tersebut telah berdiri sebuah masjid yang cukup besar dan megah berukuran 10x10 meter dengan rencana berlantai 2, lantai 2 tersebut telah dicor beton namun belum digunakan, bangunan masjid tersebut tak lepas dari bantuan beberapa donator muslim seantero Indonesia yang mendapat informasi kesulitan proses pendirian masjid ini. Pada data Simas Kemenag Tana Toraja masjid Al Fattah Tondok Garotin mulai dibangun pada tahun 1966 dan berbeda dengan informasi Imam Desa Garassik yang menyatakan masjid itu baru dibangun pada tahun 2010.

Di sisi timur Masjid dekat jalan desa dibangun sebuah gereja. Gereja Toraja Jemaat Garotin, yang merupakan bagian Klasis Gandangbatu. Dibangun hampir bersamaan dengan masjid pada tahun 1980an, Gereja tersebut awalnya juga seperti masjid yang kecil saja namun kemudian diperbesar berukuran 14x10. Bangunan Gereja baru itu kemudian ditahbiskan pada 12 Juli 2016 oleh Badan Pekerja Sinode Gereja Toraja, Pdt. I. Y Pangallo.

Acara penahbisan berlangsung semarak, tenda dibangun di berbagai sisi gereja untuk menampung tamu undangan. Umat Kristen dan Umat Muslim berdatangan meramaikan acara tersebut, mereka merupakan perwakilan pengurus masjid yang diundang, selain dari kec. Gandangbatu Sillanan terdapat pula umat Muslim dari
Enrekang yang tanpa ragu hadir meramaikan acara peresmian. Umat Muslim dibuatkan tenda tersendiri dengan lokasi tempat makan yang terpisah, Imam Desa Garassik memotong dua ekor kerbau secara islami yang kemudian dimakan bersama dalam tempat dan wadah makan sendiri baik oleh umat Kristen maupun umat Islam.

Begitupula yang terjadi ketika berlangsung acara peresmian Masjid Babul Maghrib di Kaduaja tahun 2010, panitia mengundang tetua adat, kepala sekolah, pendeta dan jemaat Kristen di sekitar lokasi tanpa melihat apa agamanya. Pada acara peresmian masjid selain memotong ayam juga menyembelih sapi untuk menjamu tetamu dan pihak pemerintah yang hadir. Menurut Mathius Limin (Wawancara Maret 2019) yang saat itu masih menjabat sebagai Kepala SMKN 1 Gandangbatu Sillanan sekaligus sebagai pimpinan Tongkonan Banua Sura' Tangko Lenge, tamu undangan meski beragama Kristen dihargai dan diberi tempat tersendiri di bagian dalam masjid, informasi ini dibenarkan oleh Safruddin yang merupakan pengurus masjid dan Ne' Sama (Imam Garassik).

Dalam observasi di Pasar Buntu, pasar ini selain pasar Mebali adalah pasar mingguan yang terletak di Kec. Gandangbatu Sillanan. Letak pasar Buntu yang lebih terjangkau dari Kaduaja dan Garassik menjadikan pasar ini cukup ramai dikunjungi warga Muslim yang banyak bermukim di lembang sekitar. Terdapat cukup banyak pedagang Bugis disini, terlihat warga berbeda agama berbaur begitu saja, di beberapa tempat terlihat perempuan dewasa beragama Kristen bercengkrama dengan sahabat karibnya yang menggunakan jilbab, warga Kristen Indo Sel yang penulis ajak mengobrol mengatakan di tempat itu tidak ada pengunjung yang memilih pedagang berdasarkan identitas agamanya, begitupula yang muslim tak pernah menolak berbelanja ke pedagang Kristen. Pasar yang umumnya ramai pada siang hari tersebut merupakan pasar tradisional yang juga menyediakan minuman tradisional warga Toraja berupa Ballok (Tuak). Lokasi penjualan minuman tersebut ditempatkan pada bagian belakang pasar, selain Ballok juga terdapat penjual daging babi, warung bakso babi dan lainnya. Menurut 
Semuel saudara Muslim sudah faham itu daerah terlarang bagi mereka, kecuali beberapa pemuda yang memang juga membeli Tuak.

Selain Kopi, Tuak adalah minuman khas yang sangat digemari orang Toraja, di sudut kota besar seperti Rantepao, Makale hingga di pelosok kampung-kampung terdapat penjual minuman ini. Minuman yang disadap dari pohon aren tersebut selalu tersedia dalam setiap hajatan warga, bahkan dianggap belumlah sempurna sebuah acara tanpa minum tuak, tuak bahkan tersebut dalam beberapa pepasan todiolo Aluk Todolo. Dalam keseharian juga warga minum tuak sambil beristirahat sepulang dari ladang atau dari sawah, begitu halnya dalam kegiatan gotong royong bercocok tanam atau menuai padi seringkali harus tersedia minuman tuak. Minuman dengan kadar alcohol ringan tersebut dapat memabukkan jika diminum dalam jumlah yang banyak, minuman tersebut dipercaya bisa meningkatkan vitalitas dan mengembalikan tenaga yang telah terkuras.

Sehari-hari banyak remaja dewasa yang berkumpul bercengkrama seringkali membentuk lingkaran sambil main gitar menikmati Ballok secara bersama-sama dalam satu gelas yang digilir. Pada beberapa tempat terdapat juga pemuda beragama Islam yang ikut bergabung minum ballok bersama-sama dengan sebayanya yang non Muslim. Menariknya, meski mereka sedang minum yang memabukkan tetap saling menghargai dengan yang berbeda agama. Seringkali acara minum ballo yang disertai makan babi tersebut jika ada pemuda Muslim gelas tempat minumnya menggunakan gelas lain yang berbeda. Menurut Semuel dan Yosi yang sering berbaur bersama pemuda Muslim minum bersama di Kaduaja "Meski sedang mabuk, tak pernah sekalipun kami menjebak saudara Muslim untuk makan babi, bagi kami itu adalah dosa besar". Bahkan dalam acara seperti itupun mereka masih menghargai saudaranya yang diharamkan makan babi.

Keakraban pemuda Muslim dan Kristen terbawa dalam kegiatan gotong royong bersama dalam kehidupan sehari-hari. Dalam observasi di Tondok Garassik terlihat beberapa orang Kristen membantu pembangunan rumah warga Muslim, kebiasaan bergotong royong dalam membangun rumah kayu merupakan sebuah kebiasaan yang juga dapat ditemui pada masyarakat Bugis Makassar terlihat cukup meriah di kampung ini. Di bagian dapur kaum wanita Kristen dan Muslimah bahumembahu menyiapkan makanan sambil berbincang akrab.

Di sudut Lembang yang lain, pada sebuah sawah milik seorang Kristen sedang berlangsung kegiatan menanam padi. Kegiatan tersebut diikuti oleh beberapa wanita beragama Islam yang belepotan lumpur bersama saudara-saudaranya yang beragama Kristen. Selepas menanam padi bersama mereka beristirahat di pematang dekat dangau makan bersama sambil mengobrol setelahnya mereka bersantai meminum kawa (Kopi tanpa gula). Menurut Ne Sama (wawancara marett 2019) hal seperti ini merupakan pemandangan biasa dalam kehidupan sehari-hari warga Garassik dan sekitarnya.

Hari yang lain ketika melintasi sebuah sekolah SD, terlihat beberapa siswa berjilbab berjalan bergerombol bersama teman sekolahnya yang beragama Kristen, letak sekolah yang cukup jauh dengan kondisi jalan menanjak dan menurun membuat mereka harus berjalan bersama sebayanya agar tidak lelah. Dalam perjalanan selain mengobrol mereka juga kadang bermain bersama, suasana tersebut merupakan keseharian warga dan tak pernah kedengaran ada orang tua yang melarang anaknya bergaul dengan yang berbeda agama. Menurut Semuel yang pendidikannya dari SD hingga SMA di Kaduaja/Gandangbatu, sekolahnya yang terletak cukup jauh dari rumah setiap hari berangkat bersama, bermain dan bercengkrama bersama dengan teman Muslim itu membangun keakraban sehingga merekapun berbaur bermain bersama di halaman masjid menunggui saudaranya yang sedang tarawih ketika bulan puasa tiba.

Pada sebuah acara Rambu Tuka' Rampanan Kapa' (pengantin) yang dihelat seorang warga Kristen di Tondok Banglak, Lembang Kaduaja, Kec. Gandangbatu Sillanan warga Kristen dan Muslim berbaur tanpa sekat, mereka saling bekerjasama tanpa melihat identitas agamanya. Dalam observasi yang kami lakukan terlihat puluhan perempuan 
berjilbab yang sedang memasak, ada pula yang bergabung mengiris daging sapi, dan Kambing, babi. Di kelompok sebelahnya dalam rombongan perempuan yang hampir sama banyaknya nampak kaum wanita Kristen mengiris daging babi, kaum Muslim tahu belaka mereka tidak akan dibiarkan bergabung dengan mereka yang mengolah babi meski dalam proses penyembelihan masih terdapat pemuda muslim yang membantu mengangkut potongan daging babi.

Walaupun pelaksana kegiatan beragama Kristen tapi ketua panitia beragama Islam, proses pemotongan hewan ayam, kerbau dan kambing menggunakan syariat Islam oleh imam setempat. Dan karena pembauran itu kegiatan masak daging Babi dan Sapi serta jenis makanan yang halal untuk Muslim menggunakan wadah dan dapur berbeda. penulis sendiri disuguhi daging sapi setelah kaum perempuan meminta kode untuk jenis makanan apa yang disuguhkan, Babi atau Sapi. Pada hari resepsi pernikahan dalam menjamu tetamu terdapat dua lokasi prasmanan terpisah, satu lokasi diperuntukkan dan merupakan makanan yang dijamin halal karena dikelola dan dilayani muslimmuslimah. Para tetamu Muslim tak akan pernah ragu dengan melihat barisan pelayan yang menggunakan jilbab melayani mereka.

Praktik kerukunan itu juga nampak dalam kehidupan pasangan nikah berbeda agama di sudut lain Tondok Banglak. Indo Aan salah satu contoh nikah beda agama yang tetap menjalani kehidupan sehari-harinya dengan harmonis di Lembang Kaduaja. Meski pernikahan mereka tak pernah terdaftar dalam catatan administrative resmi namun hal itu tak menghalangi mereka berbahagia mengayuh bahtera rumah tangga dengan rukun. Pasangan Indo Aan dengan lelaki Toni telah dikaruniai seorang anak, Toni yang berprofesi sebagai seorang petani dulu adalah seorang Pemuda Gereja yang taat dan orang tuanya merupakan tokoh masyarakat Kristen yang memberikan tanahnya untuk pembangunan Gereja Toraja di Kaduaja.

Indo Jek yang bersuamikan seorang Muallaf bercerita di kampong tersebut meski banyak yang nikah beda agama namun tetap harmonis menjalin kehidupan sehari- hari. "...sama dengan adek saya ini Indo Aan saya bilang 'tidak mubilang-bilangka sama suamimu masukmi saja Islam karena malasmi juga ke gereja', terus saya tanya lagi sama suaminya 'tidak mubilang-bilangka juga sama istrimu masukmiko saja Kristen' terus terang saya pusing melihat mereka tidak terdaftar pernikahannya, tidak ada buku nikahnya, dan menurut saya yang mereka lakukan ini hal yang dilarang dalam agama Islam".

Ambe Aan meski beragama Kristen namun pada saat kelahiran sang anak dulu dia meminta anaknya diaqiqah. Indo Aan berkata "Dulu malah bapaknya yang bilang diaqiqah", menurut Indo Jek " dulu saya berkata meski ini aqiqah ajaran sunnah rasul namun kan status perkawinanmu tidak jelas jadi yaa tak usah diaqiqah tapi Ambe Aan yang saat itu berada dalam perantauan menelpon bilang Aqiqahkan saja saya sudah ikhlas 'aqiqahmi saja', Ambe Aan sangat mendukung anaknya diaqiqah.

Setelah anaknya diaqiqah terdapat pernikahan massal secara Kristen di Gereja, "saya menganjurkan Indo Aan ini menikah secara Kristen di Gereja bilang ee masukmiko disitu ambil buku nikah di gereja, sekalian ganti agama Kristen saja daripada tidak terdaftar, pernah juga ada pernikahan massal secara Islam di Enrekang tidak mau juga, yaaa terserah kalianlah" ini kesulitan yang harus dihadapi pasangan nikah beda agama. Sang suami yang merupakan putra dari seorang anggota Majelis Gereja tentu tak bisa melanggar pesan orangtua untuk menjaga kekristenannya, cukup berat menjaga pesan orang tua yang sudah meninggal, Indo Jek bercerita "bapakna suamina ini memang sesepuh gereja toraja daerah sini, asalnya keluarga Kristen yang taat, ada yang pendeta, nabilang tidak boleh dilanggar itu pesanna orang tua yang sudah meninggal kasian".

Nikah beda agama cukup lumrah ditemui pada kampong yang bercampur dan berbaur tanpa sekat di Lembang Kaduaja. Indo Jek yang juga merupakan seorang guru ngaji di Tondok Kaduaja dulu ketika akan menikah dengan seorang pemuda Kristen memang cukup teguh memegang keislamannya. "kalo saya kan kebetulan suami saya juga muallaf, dulu ketika akan menikah dengan pacar Kristen itu dulu agama yang nomor satu yang 
saya pegang jadi saya bilang 'kau masuk Islam atau saya masuk Kristen' terus dia bilang 'maukokah masuk Kristen?' sayajawab 'terus terang saya tidak bisa masuk Kristen karena saya kan guru ngaji, apa nanti kata orang-orang, lagian kan kau kurang rajinji kuliat ibadah di gereja jadi mungkin rajinnya kau nanti kalo sudah masuk Islam, Alhamdulillah rajin betul dia' saya kan juga melihat dia juga kurang rajinji masuk gereja jadi lebih baik diislamkan saja. Kami ini lima bersaudara semuanya muallaf suaminya, hanya Indo Aan yang belum muallaf karena kendala pesan orang tua tapi akur saja".

Pasangan ini meski sudah menjalin nikah beda agama selama bertahun-tahun namun tak pernah terjadi konflik. Yang menarik adalah sang suami yang terus menganjurkan untuk menyumbang ke Masjid dan juga selalu bersedia membayarkan zakat fitrah buat sang istri dan anaknya bahkan dia protes "kenapa sedikit sekali dibayar fitrah?". Begitu pula sang istri, Indo Aan bercerita "dulu ada iuran bulanan atau mungkin berupa sumbangan tergantung besarnya penghasilan jemaat yang dibayarkan ke Gereja oleh jemaat dan suami saya termasuk anggota gereja yang tidak peduli, tapi saya membayarkan iurannya selama beberapa tahun, saya bilang sama Indo'na Muel kenapa tidak datang kerumah saya mau bayar iuran untuk suami, tapi ndak pernahmi lagi datang padahal sudah memangmi kubilang klo ada apa-apa mau dikasi masuk (disumbang) ke Gereja bilang saja."

Indo Jek bercerita sepanjang ingatan dalam hidupnya tak pernah terjadi konflik dalam rumah tangga yang disebabkan oleh agama. Beliau bersaksi untuk sang adik, Indo Aan "kalau ada kegiatan di gereja masuk juga di gereja mendukung dan terlibat disitu, ada kegiatan di masjid masuk juga di masjid mendukung dan sang suami kadang juga ikut membantu, ini anaknya kan Islam klo tidak pergi mengaji disuruh diusir sama bapaknya yang Kristen 'pigi mengaji sana, mau jadi apa kau itu?' jadi kami disini memang terjaga ini toleransi antar umat beragama, beda dengan kampung-kampung yang lain". Indo Jek yang cukup berpendidikan merasa gamang melihat masa depan anak-anak yang lahir dari pernikahan tanpa catatan resmi selalu menganjurkan untuk mempersatukan agamanya Kristen atau Islam. Namun, pasangan suami istri beda agama ini cukup acuh karena merasa baik-baik saja menjalani biduk rumah tangganya. Indo Jek lanjut bertutur "saya pernah berkata bagaimana nanti itu anakmu klo sudah besar nanti namun jawabannya 'kasi begitu bangmi (begitumi saja), nantipi klo sudah dewasa kan nataumi mana yang baik mau ikut ambe'nya atau indo 'na sama saja."

Menurut Indo Aan, suaminya karena menghormati agama istrinya dia tidak makan babi, menurutnya mungkin penghormatan inilah yang membuat keluarganya saling menghargai. Saat tiba bulan puasa, sang suami selalu membangunkan dan menemani bersantap sahur, saat senja tiba sang istri membuat takjil berbuka puasa suami tidak pernah makan kue sebelum tiba waktu berbuka "nanti klo sudah buka puasa orang baru kita makan kue sama-sama". Pernah juga tiba giliran mengantar takjil buka bersama di masjid sang suami dengan ikhlas membantu mengantarkan, Indo Aan bercerita saat sang suami makan siang dia selalu bersembunyi dan tak mau dilihat bahkan tak mau dilayani sang istri, dia mengerti orang puasa tak baik jika melihat orang sedang makan. Indo Aan juga selalu memaksa sang suami ikut ibadah Natal dan tahun baru, pernah juga ketika masih aktif pelayanan dari gereja di rumahnya dilaksanakan ibadat rumah tangga dan indo Aan sebagai Muslim sukarela melayani penganan ringan dan makanannya.

Kedua pihak keluarga pasangan ini juga mendukung saja dan tidak pernah mempermasalahkan meski berbeda agama. Indo Jek yang bersuami seorang muallaf bercerita keluarga suaminya sangat baik meski Kristen semua dan beliau terlibat aktif dalam setiap acara-acara keluarga, "Kami disini sudah saling memahami agama masingmasing, klo ada acara masukka disitu terlibat langsung, misalnya klo mengiris-iris daging kami juga ikut meski berbeda karena biasanya jika keluarga Kristen yaa ada babinya kami tidak ikut, kami hanya iris-iris dan masak daging ayam atau sapi kerbau yang halal, orang disini juga faham semua karena itu 
dibedakan tempatnya, baik tempat mengiris daging maupun tempat memasak dan wadah makannya, mereka juga tau klo Muslim tidak boleh pegang babi, jadi tidak ada itu yang mau-maunya ngerjain, klo saya duduk disuatu tempat pernah ditegur 'adek jangan disini karena ada daging babi' jadi begitu kita saling toleransi tanpa pernah diajari oleh siapapun".

Indo Aan dan Indo Jek mengisahkan pernah ada keluarga suami beragama Kristen yang meninggal di rumahnya dan keluarga Kristen faham tidak boleh potong babi karena meninggal di rumah orang Muslim, keluarga Kristen juga mengerti "Janganmaki potong babi karena rumahnya orang Islam". Tetap melaksanakan ibadah pelepasan jenazah di rumah keluarga Muslim tersebut namun tidak ada orang makan babi dan hanya memotong kerbau yang disembelih menggunakan cara Islam oleh Imam Desa. Di Lembang tersebut setiap ada kegiatan yang merupakan acara keluarga pemotongan Kerbau selalu dilakukan dengan cara Islami karena banyak keluarga beragama Islam "Di tondok ini seumpama dirumahnya Muel yang Kristen ada acara yang potong hewan itu Islam karena banyak juga keluarganya yang Islam, mereka faham klo Kristen yang potong tidak ada Islam mau makan."

Hal ini sejalan dengan penuturan $\mathrm{Ne}^{\prime}$ Sama' seorang Imam Desa Garassik yang sering diundang untuk memotong hewan dalam sebuah acara orang Kristen. Acara Rambu Tuka' Rampanan Kapa (pesta Pernikahan) maupun Rambu Solo (adat kematian) biasanya melibatkan kerabat, keluarga maupun tamu undangan yang beragama Islam dan orang Kristen faham saudara Muslimnya tidak boleh makan yang dianggap tidak halal, menurutnya umat Muslim disini cukup tahu dan tak pernah kuatir akan disuguhi makanan yang tidak halal.

Kepala Lembang Kaduaja juga berasal keluarga yang berbeda agama, pertalian kerabat Kristen dan Islam di Toraja memang merupakan hal yang biasa, "Dulu Kepala lembang kami ini juga Islam tapi ada istrinya Kristen dengan satu anak, lembang yang sekarang juga ada saudaranya dan banyak keluarganya yang Kristen, meskipun dia kayaknya ustadz tapi toleransinya juga bagus".

Dalam kehidupan sehari-hari di Lembang Kaduaja memang tidak terdapat sekat antar keyakinan berbeda, hal ini terlihat dalam perbauran warga ketika berlangsung pertandingan olahraga Bola Volly di halaman Tongkonan Tanete Surruk dan pertandingan Sepak Takraw di halaman Gereja Toraja, perhelatan ini diinisiasi oleh Karang Taruna Lembang Kaduaja. Remaja muslim yang mayoritas beraliran Muhammadiyah berkerudung berbaur dengan remaja Kristen saling membantu klub masing-masing untuk memenangkan pertandingan, terlihat pula pemandangan sejuk serupa pada barisan penonton yang bergaul dengan sebaya maupun adik-kakaknya tanpa melihat identitas agamanya.

Ketika ada orang Islam yang meninggal juga warga Kristen berbaur bahkan banyak yang ikut bertakziyah menyumbangkan harta benda, uang, beras dan lainnya sebagai tanda dukacita bahkan ikut makan bersama dalam tradisi tahlilan tiga hari, tujuh hari maupun empat puluh hari. Sebaliknya juga begitu ketika ada umat Kristen yang meninggal, keluarga, kerabat tetangga juga ikut menyumbang bawa gula, minyak, bawa beras untuk dimasak, ada yang membawa uang duka dan terlibat langsung dalam prosesi pemakaman meskipun tetap tahu bagian ibadat apa yang mesti dihindari dari yang berbeda agama. Menurut Indo Jek setiap ada orang meninggal di lembang tersebut tidak dilihat apa agamanya, orang Islam dan orang Kristen datang menyampaikan bela sungkawa tanpa pernah sungkan. Tak pernah terdengar di tempat ini ada orang tidak mau datang karena persoalan agama.

Jika di tempat lain ditemukan pemakaman umum yang menolak berdampingan dengan yang berbeda agama. Maka, pada lembang Kaduaja dan Lembang Garassik mudah ditemui pemakaman bercampur baur antara yang Islam maupun yang Kristen bahkan Hindu Alukta. Pemakaman di kedua Lembang ini umumnya berada pada tempat yang tinggi, disebutkan tempat yang tinggi menjadi tempat yang baik 
untuk berjalan pada "Yang Diatas" atau menuju Puya (Surga).

\section{Torayaan Mencipta dan Merajut Harmoni}

Komunitas masyarakat Lembang Kaduaja, Lembang Garassik dan umumnya di wilayah Toraja yang masih mempraktikkan kerukunan beragama dengan baik itu, ternyata salah satunya ditunjang oleh kearifan lokal yang ada pada masyarakat tersebut. Dibanding dengan ajaran agama masing-masing kelompok yang bersifat universal, kearifan lokal relatif lebih bisa diterima sebagai praktik bersama di masyarakat. Masyarakat Tanah Toraja misalnya, mereka bisa membangun kehidupan yang guyub hingga hari ini karena ditunjang oleh kearifan lokal yang disebut dengan tongkonan. Tongkonan ini menjadi sistem sosial-budaya yang mempersatukan rumpun keluarga yang berbeda agama.

Sistem kekerabatan orang Toraja (Torayaan) diikat dalam suatu Tongkonan "Dimanapun dia berada sejauh apapun dia pergi, dia terikat pada tongkonannya" (Daud Sangka Palisungan, Wawancara Februari 2019). Di kalangan orang Toraja sistem kekerabatan hingga sepupu lapis ke tujuh tetap dianggap sebagai saudara, mereka terikat dalam sebuah tongkonan. Tongkonan adalah sebuah sistem pranata keluarga yang disimbolkan dengan sebuah bangunan tradisional khas Toraja. Setiap orang Toraja menjadi anggota Tongkonan yang dibangun oleh leluhurnya baik menurut garis bapak maupun menurut garis ibu. Selain itu iapun menjadi anggota persekutuan saroan (persekutuan kerja dari kelompok tetangga), anggota persekutuan regional yang lebih luas (penanian, ambakan datu, bua, atau lembang) Ia mempunyai hak dan kewajiban dalam persekutuan itu, persekutuan geneologis dan perekutuan regional atau territorial (persekutuan karena ikatan kesatuan atau kediaman) sebagai suatu ikatan persekutuan adat atau aluk (Sarira, 1996:55).

Salah satu hal yang menjadi milik kekayaan tongkonan adalah Aluk yang bisa didefinisikan adat atau agama, hukum adat (agama) yang meliputi seluruh aspek hidup berupa norma atau tatacara berhubungan dengan Tuhan, Manusia dan alam semesta beserta isinya sehingga seorang Toraja tak boleh melanggar norma-norma itu dalam menjalankan kehidupannya jika dia masih merasa terikat dengan tongkonannya. Toraja menganut system kekerabatan yang berdasarkan prinsip bilaterial, setiap orang menjadi anggota tongkonan baik dari pihak bapak maupun pihak ibu seperti disebutkan sebelumnya menyebabkan setiap orang menjadi terikat, menjadi anggota dan bertanggung jawab pada lebih dari satu tongkonan.

Tongkonan memiliki fungsi sebagai pemegang kekuasaan dan peranan adat yang menjadi adat stabilisator social dan berkembang terus menerus selain itu tongkonan juga berfungsi sebagai pusat perikatan keluarga sebagai pangkal lahirnya persatuan serta hubungan kekeluargaan yang sangat erat dan dibuktikan dengan kegotongroyongan dalam berbagai hal (Tangdilintin, 1980: 159). Sebagai sebuah kebanggaan keluarga (klan) sering nampak terjadi persaingan antar tongkonan dalam melaksanakan kegiatan-kegiatannya, yang paling kasat mata adalah dalam hal kemeriahan, kemewahan dan kemegahan pelaksanaan sebuah pesta adat. Salah satu tanda kemegahan itu adalah seberapa banyak kurban persembahan Kerbau, babi (bahkan kambing bagi yang sudah Islam), oleh karena itu semua warga tongkonan akan berusaha semaksimal mungkin untuk berpartisipasi dalam sebuah perayaan. Hal tersebut dilakukan untuk menancapkan pengaruh sebuah klan dalam suatu wilayah, pencapaian kekuasaan politis, juga berarti penguasaan sumbersumber ekonomi.

Di Lembang Kaduaja terdapat sebuah tongkonan bernama Tongkonan Tanete Surruk sebagai bagian (anak-turunan) dari Tongkonan Kaduaja dan Batupesse yang dibangun oleh seorang anggota DPRD Tana Toraja dari PKS pada tahun 2015, Tongkonan ini disebut sebagai Tongkonan Batu A'riri yang berfungsi sebagai tongkonan persatuan keluarga yang kuat dan tempat pembinaan warisan keluarga tetapi tongkonan jenis ini tidak mempunyai kekuasaan atau peranan adat. Penghuni dan anggota keluarga tongkonan Tanete Surruk bercampur antara yang beragama Islam 
maupun Kristen, mereka mempunyai hak dan kewajiban yang setara dalam menjaga nama baik tongkonannya, menjaga nama baik kerabatnya. Selain pada satu tongkonan Tanete Surruk ini hampir semua anggota klan juga merupakan anggota dari tongkonan lain, baik dari garis turunan ayah ataupun ibu, seorang pemuda Semuel menyebutkan dia merupakan seorang anggota Tongkonan Batu Pesse, Tongkonan Kaduaja dan Tongkonan Buntu Tangnga yang sudah berada dalam wilayah Enrekang.

Jalinan kekerabatan yang diikat dalam sebuah tongkonan membuat orang Toraja memupuk dan membina rasa kekeluargaan antar masyarakat. Hal ini disebutkan menjadi ciri khas kepribadian masyarakat Toraja (Tangdilinting, 1980: 181). Karena setiap anggota masyarakat mengenal dan mempunyai tongkonannya serta mempunyai kewajiban mengabdi pada tongkonannya untuk menjaga dan sebagai pewaris kearifan lokalnya. Hubungan kekerabatan inilah yang membuat warga Toraja menjadi terbiasa berinteraksi dengan yang berbeda agama dan mempengaruhi sikap tindaknya dalam kehidupan sehari-hari.

Di Kaduaja berdomisili seorang Anggota DPRD Tana Toraja dari PKS, beliau telah 2 periode (2009 dan 2014) menjadi legislator. Lumbung suara Pak Safruddin bukan hanya di kalangan warga Muslim namun juga dari warga Kristen. Menurut Ambe Muel (wawancara 2019) di Kaduaja tak pernah dilihat latar belakang identitas keagamaan dari seorang calon tapi lebih kepada bagaimana sang caleg diharapkan bisa memperjuangkan aspirasi pembangunan di kampung. Indo Muel (beragama Kristen) yang merupakan sepupu dari pak Safruddin mengungkap selama ini cukup banyak proyek yang diperjuangkan pak dewan (Safruddin) karena itu cukup disenangi oleh warga. Pada beberapa rumah warga Kristen memang terlihat tanda gambar Safruddin dan bendera PKS berkibar. Pak Safruddin merupakan warga Tongkonan Kaduaja yang memiliki jaringan kerabat cukup luas dan cukup aktif terlibat dalam kegiatan Tongkonannya.

Dalam sebuah upacara tongkonan, semua anggota klan meskipun berbeda agama merasa wajib berpartisipasi. Di hampir seluruh wilayah Gandangbatu Sillanan sejak berpuluh tahun silam setelah konversi agama samawi terjadi beberapa penyesuaian pelaksanaan kegiatan upacara adat (Mathius Limin, Wawancara maret 2019). Hal ini dilakukan untuk mengakomodasi dan menghargai agama warga tongkonan yang berbeda-beda. Proses pemotongan hewan ayam, kerbau atau kambing telah menggunakan syariat Islam dengan mengundang imam/guru sara' yang berkompeten, begitupun keluarga Muslim akan dibuatkan lantang (balai-balai/tenda) tersendiri untuk mengelola makanan halalnya, setiap orang Toraja dibekali pesan untuk $n a$ pomelo to sangrapu tallang, na pobalo' to sangkaponan ao' iana rannuanna to sangrapu (membawa kebaikan bagi orang serumpun bambu, menjadi tumpuan harapan keluarga serumpun), mereka juga dibekali dengan pesan umpesalai kakadakean tu la urrampoi to senga' (menghindarkan bahaya yang akan menimpa orang lain). Kasiturusan atau ambakan datu merupakan harga diri dari masyarakat toraja sehingga mereka bergotong royong dan bekerja sama melaksanakan pekerjaan baik rumpun keluarga dalam tongkonan, pun yang tidak ada hubungan darah daging (Tarrapa, TT: 11).

Transformasi pesan leluhur melalui berbagai jenis sastra lisan dalam masyarakat Toraja seringkali dilaksanakan melalui wadah tongkonan baik dalam bentuk duduk bersama (ma'tongkon) maupun dalam berbagai perayaan keluarga tongkonan. Kebiasaan ini terbawa dalam kehidupan sehari-hari, warga terbiasa berkumpul menghabiskan waktu bersama untuk mengobrol, saling bertukar cerita sambil minum kawa (kopi tanpa gula). Kegiatan berkumpul bersama ini dalam amatan sehari-hari dilakukan di bagian beranda (lego-lego) rumah, siapapun yang melintas akan diajak bergabung.

Meskipun pada Lembang Kaduaja dan Lembang Garassik tongkonan yang ada hanya berada pada tingkat Tongkonan Batu A'riri yang tidak memiliki kekuasaan adat namun keberadaan tongkonan ini cukup mengikat warganya, warga yang muslim dan Kristen cukup menghargai peran tongkonan untuk mempersatukan warga. Ne Sama dan MA 
(Wawancara maret 2019) sebagai pendatang Bugis mereka harus menyesuaikan diri dengan kondisi budaya setempat dan menjunjung tinggi adat istiadat yang dianut penduduk. $\mathrm{Ne}$ Sama yang sejak lahir tinggal di Garassik bahkan menyitir sebuah Tuleran Kada "Kapua naria aluk, kasalle sitilan sangka'-Tuo lan kapotonganan tontong umpentoi otoran sia adat budaya setempat" secara harafiah jika diartikan bebas berbunyi "besar dipangku agama, dewasa tetap disertai teladan-Hidup beriman dan taat pada adat/budaya setempat". Menurutnya selama kita mampu menyesuaikan diri dengan budaya setempat maka akan tercipta kedamaian dan kerukunan dalam masyarakat.

Berbagai kalangan menyebut kerukunan antar umat beragama di Tana Toraja itu bisa tercipta selain dipengaruhi oleh system kekerabatan tongkonan juga oleh aluk (dalam artian adat istiadat). Tongkonan menjaga aluk yang melahirkan kearifan lokal yang dianut warga berdasar petuah leluhur (pepasang todiolo) diantaranya dalam sebuah ungkapan yang cukup dikenal orang Toraja "la'bi keangga tu rara na ia aluk" yang bermakna "lebih berharga ikatan persaudaraan/kekerabatan daripada agama". Pepasang Todiolo tersebut cukup mengikat warga Toraja meskipun dia bukan lagi menganut agama asli Toraja, Aluk Todolo. Bagi orang Toraja pesan leluhur adalah petunjuk penting agar memperoleh kebaikan dan kedamaian dalam kehidupan.

Nilai karapasan (kedamaian) dalam persekutuan atau komunitas merupakan nilai dasar sekaligus tujuan dari semua nilai-nilai dalam falsafah tongkonan, karena nilai ini merupakan usaha mempertahankan dan memelihara kedamaian, kerukunan dengan sesama warga masyarakat tongkonan agar tetap tercipta kehidupan yang harmonis bahkan mengorbankan kekayaan demi terciptanya keharmonisan. Hal ini terungkap dalam ungkapan "unnalli melo, atau la'biran tallan tu barang apa kela sisarakmira tu rara buku" (Unnalli melo secara harafiah diterjemahkan membeli kebaikan, artinya apa yang baik dalam konteks kedamaian dan harmoni. La'biran tallan tu barang apa kela sisarakmira tu rara buku secara harafiah lebih baik harta benda hanyut daripada rusak hubungan dara daging artinya orang rela mengorbankan harta bendanya, daripada mengorbankan persaudaraan). Ini adalah bukti bahwa orang toraja mencintai kedamaian dan hubungan yang baik. Orang toraja harus bersedia menderita demi kebaikan dalam komunitas (Tarrapa, TT: 14).

Salah satu alasan yang menyebabkan kearifan lokal ini bisa menjadi unsur penting dalam menguatkan toleransi adalah kekuatannya untuk merekatkan masyarakat. Kearifan lokal bisa menjadi daya rekat, karena masyarakat secara bersama-sama bisa menerima aturan moral yang ada dalam kearifan lokal tersebut. Masyarakat bersangkutan menilai kearifan lokal adalah kesepakatan bersama yang telah dijalankan secara turun-temurun dan menghasilkan kemanfaatan bagi mereka. Tentu kearifan lokal yang bisa menguatkan kerukunan ini adalah kearifan lokal yang masih terus dipraktikkan, bukan hanya sekedar nilai-nilai yang abstrak. Pada warga Lembang Kaduaja dan Garassik kearifan lokal yang mereka miliki senyatanya masih berfungsi mengatur dan mengelola berbagai praktik dalam kehidupan bermasyarakat.

Kuatnya nilai-nilai kerukunan dan kedamaian yang tertanam dalam kearifan lokal Toraja diharapkan tetap menjadi benteng yang tangguh untuk menepis budaya negatif dan ekstrim yang bisa datang dari luar. Nilai budaya lokal inilah yang dipercaya menjadi penangkal efek negatif yang bisa merembes dari kekacauan bernuansa SARA yang terjadi di wilayah yang bertetangga dengan Poso dan Mamasa, Ambon dan berbagai isu yang memicu aksi intoleransi pada tempat lain.

\section{PENUTUP}

Lembang Kaduaja dan Lembang Garassik di Gandangbatu Sillanan Kabupaten Tana Toraja adalah sebuah wilayah setingkat desa yang terletak bersebelahan dengan Kabupaten Enrekang. Komposisi penduduk kedua lembang ini terdiri dari penganut agama Kristen, Katholik, Islam dan Hindu Alukta. Selain itu dari segi etnis terdapat cukup banyak warga yang merupakan turunan Bugis maupun 
Enrekang serta etnis lain yang hidup berdampingan dengan rukun dan harmonis.

Warga Lembang Kaduaja dan Garassik mempraktikkan kerukunan dalam kesehariannya secara alamiah, warga tak mempersoalkan identitas agama, mereka tetap menjalin hubungan dengan kerabat ataupun orang lain yang berbeda agama. Relasi aktif mereka tunjukkan dalam kehidupan seharihari; relasi persahabatan, saling membantu bergotong royong dalam aktifitas pertanian, perkebunan, membangun rumah bahkan hingga keterlibatan aktif dalam pembangunan rumah ibadat umat lain. Disini bahkan banyak ditemukan warga yang dalam satu rumah berbeda agama, ada yang ayahnya Hindu (Alukta) anaknya Kristen. Di lembang Garassik, Tondok Garotin, pada sebuah tempat yang sama Masjid dan Gereja dibangun berdampingan oleh warga secara swadaya.

Penting dilakukan proteksi terhadap pengaruh ekstrim yang bisa melahirkan aksi intoleran dengan kearifan lokal yang dianut oleh masyarakatnya. Pesan leluhur untuk siangga, sikamali na siangkarran (saling menghargai, saling merindukan dan saling tolong menolong) terus menerus ditransformasikan melalui petuah bijak dengan tradisi lisan terhadap generasi muda. Warga Toraja membangun keramahan kepada siapa saja dan tak boleh memupuk rasa curiga (tang sipatongan).

\section{UCAPAN TERIMAKASIH}

Dalam suatu penelitian, dari awal sampai akhir pasti banyak pihak yang terlibat. Untuk menyebutnya, tidak cukup halaman ini untuk mencatatkannya satu persatu. Dari itu, ucapan terima kasih yang tak terhingga kepada para informan di lapangan, pihak Kemenag, FKUB dan dosen serta mahasiswa STAKN Tana Toraja, khususnya para pembantu lapangan yang selalu penulis repotkan dengan pertanyaan tentang berbagai istilah Toraja, terkhusus informan yang penulis wawancarai berkali-kali dan cukup menyita waktu, kurre sumange budak!; juga ucapan terima kasih kepada rekan sejawat di bidang Bimas dan Layanan Keagamaan pada Balai Penelitian dan
Pengembangan Agama Makassar dan sejawat bidang lain serta staf kantor yang rela berbagi berdiskusi dan bertukar fikiran. Pada akhirnya redaksi Alqalam yang berkenan memuat tulisan ini.

\section{DAFTAR PUSTAKA}

Andaya, Leonard Y. Warisan Arung Palakka; Sejarah Sulawesi Selatan Abad Ke.17: Makassar, Ininnawa, Cetakan 2 Mei 2006

Batong, Hermin. 2007. Sejarah Islam di Massenrempulu, dalam Jurnal (SULESENA) Sejarah Sulawesi Selatan, Tenggara dan Barat. Makassar, Balai Pelestarian Sejarah, 2007

Baturante, Nurdin. 2019. Toraja Tongkonan dan Kerukunan. Makassar. Pustaka al Zikra.

Bemmelen, Sita van dan Raben, Remco (ed). Antara Daerah dan Negara; Indonesia Tahun 1950an; Pembongkaran Narasi Besar Integrasi Bangsa. Jakarta, Yayasan Pustaka Obor Indonesia; KITLV-Jakarta, 2011

Bigalke, Terrance W. Sejarah Sosial Tana Toraja: Yogyakarta, Penerbit Ombak, 2016

BPS Tana Toraja. Gandangbatu Sillanan dalam Angka, Tana Toraja, BPS Tana Toraja, 2018

BPS Tana Toraja. Tana Toraja dalam Angka, Tana Toraja, BPS Tana Toraja, 2018

L. Eck, Diana. 2006. "What Is Pluralism?"” http://pluralism.org (12-12-2018)

End, Th. Van den. Sumber Zending tentang Sejarah Gereja Toraja 1901-1961. Jakarta. Gunung Mulia. 1991

Kec. Gandangbatu Sillanan. Profil Kecamatan Gandangbatu Sillanan. Tana Toraja. 2004

Mappasanda, H.A.M. Massenrempulu dalam Catatan D. F. Van Bram Morris. Ujung Pandang. Balai Kajian Sejarah dan Nilai Tradisional, 1991/1992.

Sarira, YA. Rambu Solo dan Persepsi Orang Kristen tentang Rambu Solo: Tana Toraja, Pusbang Gereja Toraja, 1996

Sewang, Ahmad M. Islamisasi Kerajaan Gowa (Abad XVI sampai Abad XVII)- 
Cetakan ke 2. Jakarta, Yayasan Obor Indonesia, 2005

Tarrapa, Setrianto, 2018: Makalah Seminar Hasil Penelitian STAKN Tana Toraja TA 2018. Pendidikan Karakter Berbasis Budaya Toraja

Tangdilintin, L.T. Toraja dan Kebudayaannya: Tana Toraja, Yayasan Lepongan Bulan (YALBU), 1981.

Walzer, Michael. 1997. On Toleration. London: Yale University Press 